\title{
THE EFFECT OF GEOGRAPHICAL FACTORS ON ISLAMIC BANKING SUSTAINABILITY PERFORMANCE: AN INSTRUMENTAL VARIABLE QUANTILE REGRESSION ANALYSIS
}

\section{(D) Teguh Budiman ${ }^{1+}$ \\ Erie Febrian ${ }^{2}$ \\ Yudi Azis ${ }^{3}$}

\author{
${ }^{1,2, s}$ Department of Management and Business, Faculty of Economics and \\ Business, University of Padjadjaran, Indonesia. \\ 'Email:teguh.budiman1218@gmail.com \\ ${ }^{2}$ Email:erie.febrian@unpad.ac.id \\ ${ }^{3}$ Email:yudi.azis@unpad.ac.id
}

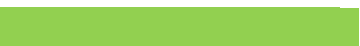

Article History

Received: 6 October 202 Revised: 22 December 2021 Accepted: 10 January 2029 Published: 24 January 2022

\section{Keywords}

Islamic banks

Maqasid financing

Commercial financing

Quantile regression.

JEL Classification: G18,G21,G38,C51,C58.
There is an ongoing debate on how Islamic banks contribute to bank sustainability. Theoretically, Islamic ethics promote sustainability, also called Maqasid al-shari'ah. This paper investigates the effect of geographical factors on Islamic bank sustainability. A theoretical and empirical model was developed to assess this relationship. It was hypothesized that geographical factors affect Islamic bank sustainability. Countries in specific geographical locations that are dominated by Islamic rules, such as the Middle East, have different magnitudes compared to east Asian countries that have fewer Islamic rules. A geographical risk model was developed according to the Maqasid alShari'ah concept and was employed based on a microeconomic banking model that portrays a variety of risks for 159 Islamic banks in ten countries. We constructed variables from macroeconomic databases, such as the World Development Indicators, and microeconomic databases, such as financial indicators and environmental, social, and governance (ESG) data from Thomson Reuters from 2012 to 2019. The analysis was conducted using panel instrumental variable regression to test the hypothesis; however, geographical risk variables produced biased results affecting Maqasid financing. The method was refined with IV quantile regression. It was found that geographical factors are strongly related to the improvement of Maqasid financing in Middle East regions, whereas in eastern regions this is vice versa. The results indicate that geopolitical factors stimulate Maqasid financing for Sustainable Development Goals.

Contribution/Originality: This paper contributes to the theoretical and empirical investigation of risk composition, especially the effect of the geographical risk variable on Islamic sustainable financing (Maqasid financing). This paper is the first study to use instrumental variable quantile regression to investigate the detailed effect of these aspects across several countries.

\section{INTRODUCTION}

The ideal perspective of an Islamic bank is achieving sustainability through a balance scale between long-term solvency and prosperity (Ahmed, Mohieldin, Verbeek, \& Aboulmagd, 2015). These aspects would impact societal well-being and contribute to environmental protection (Aliyu, Hassan, Mohd, \& Naiimi, 2017). From an Islamic bank perspective, Zulkhibri \& Ismail (2017) stated that Islamic banks could play an essential role in enhancing inclusion, such as risk-sharing contracts, and wealth redistribution, such as zakat, sadaqah, and qard hassan. In the Islamic context, financial sustainability is called Maqasid al-Shari'ah (Mergaliyev, Asutay, Avdukic, \& Karbhari, 
2021). According to Bedoui \& Mansour (2015), Maqasid al-Shari'ah is a pentagon-shaped ethical measurement to ensure that Islamic finance shares prosperity and reduces inequality and poverty, according to Koran and sunnah. These instruments are the primary mechanism of Islamic finance that assists poverty reduction. Previous studies that connect Islamic banks and sustainability include Akhtar (2000) and Zulkhibri \& Ismail (2017) for Indonesia, Bangladesh, Uganda, and the rest of the world, and they proved that Islamic banks reduce poverty. Ethically, Islamic banks are neither permitted to charge interest nor share risk-shifting where applicable, whereas Islam only acknowledges know-how risk-sharing partnerships (Çizakça, 2014). Islamic moral economy deliberately supports financial sustainability and finances poorer clients to meet moral ethics.

On the other hand, achieving Islamic bank sustainability has been challenging, as stated in empirical studies by Mergaliyev et al. (2021) and Platonova, Asutay, Dixon, \& Mohammad (2016), who highlighted that Islamic banks have failed to mandate socioeconomic and environmental issues. Mergaliyev et al. (2021) reported that the Muslim population, shari'ah, and leverage affect Maqasid performance. On the other hand, macro and socioeconomic indicators harm Maqasid performance. Budiman, Satyakti, \& Febrian (2021) reported that Islamic banks focus on proximate business objectives rather than Islamic moral economy. In a single country context, achieving a moral economy for Islamic banks is a strenuous effort. Rather than delivering sustainable performance, Bank Muamalat, one of the largest and oldest Islamic banks in Indonesia, faced difficulty prior to bankruptcy despite Indonesia being the largest Muslim country in the world. Beck, Demirgüç-Kunt, \& Merrouche (2013) reported that Islamic banks sustained in a more extended period. The Islamic banks are better capitalized, have higher asset quality, and are less likely to disintermediate during crises. Nevertheless, there is a gap between the aspirations and fundamental practices of institutions to deliver an ideal balance between institutional and welfare objectives. Further research is needed to understand how Islamic banks will achieve their moral objectives.

Furthermore, it is important to investigate why Islamic bank sustainability performance and financial performance are different. The ambiguity of results needs to be reduced by proposing different models and tools. A deeper analysis is needed to determine the connection between these aspects. Budiman et al. (2021) reported that Maqasid al-Shari'ah activity across the world is declining. Albaity, Mallek, \& Noman (2019) reported that expanding Islamic bank performance to compete with conventional banks is not easy. Islamic banks facing intense competition has led to the fragility of conventional banks. Imprudent liberalization and competition hampered banks' attainment of strengthened market power and stabilization. In conventional literature, several studies such as Scholtens \& Dam (2007); Scholtens \& van't Klooster (2019); Scholtens (2017); and Wu \& Shen (2013) support the idea that sustainability reduces bank risk, improves financial performance, and vice versa. Sustainability has forced banks to be more efficient, while at the same time reducing risk and improving their performance. Jawadi, Jawadi, Ameur, \& Idi (2017) reported that geographical environment as a risk factor positively affects Islamic bank performance. In a recent study, Mergaliyev et al. (2021) reported that macroeconomic variables, such as population, gross domestic product (GDP), financial development, and the human development index, negatively impacted Islamic bank sustainability across 12 countries. On the other hand, microeconomic performance, such as corporate social responsibility (CSR) disclosure positively affect Islamic bank financial performance (Mergaliyev et al., 2021; Platonova et al., 2016). These results support Jawadi, Jawadi, Cheffou, Ameur, \& Louhichi (2017), who stated that the heterogeneity of Islamic banks occurs due to a variety of shari'ah rules associated with cultural, macroeconomic, and monetary policy on Islamic bank policy at the country level and produces different results. The different policies can affect Islamic banking sustainability and financial performance differently. The premise stated that the different geographical factors could be the risk effect on bank sustainability and performance.

This study hypothesizes that geographical factors stimulate the difference to achieve Islamic bank sustainability and financial performance, but it is necessary to determine by how much, and which factor has the greatest effect. According to Sachs (2000), geographical factors, especially in tropical zones, are hampered by a lack of technology development in terms of natural resource utilization due to poor public health and outdated 
agriculture technology. Acemoglu, Johnson, \& Robinson (2002) stated that income difference is no longer a significant aspect of the geographical feature. Improving institutional quality stimulates better investment quality, such as agriculture, industry, and better environment investment, producing more equality in income distribution. A recent study by Imam \& Kpodar (2016) stated that geographical locations that connect with a natural resource, such as oil, are significantly linked with Islamic financial sectors. When the United States suffered a shock due to the 9/11 attack, the development of Islamic banking halted. However, geographical factors are still crucial for determining Islamic bank sustainability, such as agriculture productivity, natural resource productivity, urban area population, and climate advantage. These factors affect demand for financing and Islamic banks' capacity to meet this demand. It included the banks' capacity, such as assets, risk management, return on assets, equity, and cost of capital. Therefore, it is proposed that geographical factors improve the sustainability and financial performance of Islamic banks.

This paper contributes to both theoretical and empirical models for decomposing the Maqasid Index into microeconomic aspects of the banking production function. A theoretical model was used to assess whether geographical factors affect a variety of Maqasid financing. The method included the latest instrumental variable quantile regression to reduce the selection problems and produce consistent estimations. To the best of our knowledge, this paper is the first that connects geographical factors of Maqasid financing and portrays environment, social and governance aspects in an Islamic bank context. The findings suggest that geographical factors are crucial for Islamic banks to conduct Maqasid financing, and the empirical results strongly support the theoretical model.

\section{MODEL SETUP}

Islamic bank sustainability and financial performance activities were adopted according to the approach taken by Budiman et al. (2021). Islamic banks act as financial intermediaries, as noted by Boyd \& Nicolo (2005), similar to conventional bank activity. In order to have a similar perception of how Maqasid al-Shariah works in the generic context of sustainability, the Islamic ethics of Maqasid al-Shari'ah were mapped closely into environment, social, and government (ESG) activities, as noted by Scholtens \& van't Klooster (2019). This mapping aims to match the analogy between the Islamic perspective and the conventional perspective.

Islamic sustainability activities were separated into eight dimensions, as per Bedoui \& Mansour (2015), and mapped them into the production function category, as noted by Ahmed et al. (2015). A bank consists of three factors_-production (i.e., input), technology (i.e., process), and product (i.e., output) (Freixas \& Rochet, 2009). This concept is depicted in Table 1, which consists of bank production activities and indicators from the Maqasid alShari'ah dimension, as noted by Mergaliyev et al. (2021), and ESG terms of conventional bank sustainability.

According to Ahmed et al. (2015), Islamic banks focus on financing sustainable sectors. These sectors include inclusive financing; financing for small and medium enterprises; clean energy investment, such as renewable energy; the health and education sectors; affordable housing; and the sectors related to sustainable finance and are henceforth referred to as Maqasid financing. In contrast, commercial sectors comprise Islamic bank financing outside of those sectors. The Maqasid al-Shari'ah indicators were curated as noted by Bedoui \& Mansour (2015). We have six indicators mapped as outputs in Table 1, including [1] faith, [3] self, [6] social entity, and [8] ecology. This approach was compared with the ESG (environment, social, and governance) dimension to convince readers that Maqasid al-Shari'ah indicators have similar terminology within a conventional bank (Scholtens \& van’t Klooster, 2019). Islamic banks that improve these indicators have better sustainability.

In the process variable, as noted in Table 1, Maqasid dimension indicators, such as [1] faith, [2] human, [5] prosperity, and [8] environment (ecology), are what banks need to achieve Islamic sustainability output. According to Aliyu et al. (2017), these indicators convert a bank's input and output through its process. These process indicators guide the Islamic banks towards compliance with the Maqasid al-Shari'ah indicators and are evaluated 
and regularly controlled to ensure that the activities are feasible. The ability of Islamic banks to improve these indicators will affect the transformation of input towards output. While most of the indicators are strongly related to governance indicators, it is believed that transparency and good governance, economic efficiency, and economy of scale improve the bank's productivity (Lensink, Meesters, \& Naaborg, 2008). It is straightforward in a year to year operation when Islamic banks comply with these indicators. The results which state that sustainability reduces risk and creates efficiency are in line with those of Scholtens \& van't Klooster (2019). These process activities are crucial for Islamic banks to comply with to improve productivity.

The input variable is defined as the factor of production employed by the bank to produce output (Freixas \& Rochet, 2009). According to Boyd \& Nicolo (2005), bank productivity comprises of customer deposits or other party funds collected to produce output or financing in Islamic banking terms. According to Beck et al. (2013), other party or deposit funds in Islamic banks include wadiah, sadaqah, qard hassan or grant, zakat, and infaq, or other income, such as profit and loss sharing and personnel cost. Mapped within Maqasid al-Shari'ah indicator dimensions are [2] human, [4] mind, [5] prosperity, and [7] wealth. It is argued that better input indicators, such as deposits or other collected funds, improve Islamic banks through better processes. Hence, a generic model can be built for production functions (output, process, and input). In these terms, Islamic banks' production function is as follows:

$$
O=P(I)
$$

Where $\mathrm{O}$ is output, $\mathrm{P}$ is process, and $(\mathrm{I})$ is input. It is assumed that Equation 1 is within the perfect competition model, that Islamic banks' outputs focus on Maqasid financing rather than commercial financing. The input resources, such as deposit activities (wadiah) and zakat, infaq, sadaqah, qard hassan, and other costs as a primary funding resource for Islamic banks to finance society, also known as the banks' outputs. In order to improve productivity, banks should improve their processes.

Process is assumed to be the crucial factor that leads to efficiency and risk mitigation. When Islamic banks focus on Maqasid financing, the $\mathrm{P}$ activities require more productive factors that stimulate Islamic banks to enhance efficiency and risk mitigation. When $\mathrm{P}$ activities increase by improving the score of the listed process, the Islamic bank can mitigate the risk by complying with the indicators. Otherwise, if Islamic banks' process scores decrease, they face difficulties achieving their goals, increasing risk mitigation costs, decreasing Maqasid financing, and shifting to commercial financing. Moreover, Equation 1 is a microeconomic bank function, as noted by Freixas \& Rochet (2009), where financing is an output, deposit, or other investment or charitable funding (zakat, sadaqah, qard hassan, infaq, and waqf). To support Islamic banks, Equation 1 is revised to become:

$$
F=P(D, I)
$$

Where $\mathrm{F}$ is financing, $\mathrm{D}$ is a deposit, $\mathrm{I}$ is an investment, and $\mathrm{P}$ is process activities, which is referred to as the process index henceforth. The interaction between the process index on deposits and other investments are positive for financing because when deposits increase, the financing increases, otherwise Equation 2 does not fully reflect Islamic bank behavior in the market because banks are commercial institutions that maximize profit. This concept was devised by Boyd \& Nicolo (2005) and Satyakti, Herwany, Wardhana, \& Pamungkas (2017), who stated that Islamic banks can optimize profits as follows:

$$
\max \pi=r^{f} \cdot F-r^{d} \cdot D-\chi \cdot I \text { subject to } F=D+I
$$

Where $(\pi)$ is profit; $r^{f}$ is the financing rate or profit and loss sharing; $\mathrm{F}$ is financing; $\left(\boldsymbol{r}^{d}\right)$ is the deposit rate; and $\chi$ is another investment rate associated with other investment funding or charitable funding. In order to get an optimum rate for Islamic banks, we develop Equation 3 as the Euler-Lagrange solution as follows: 


$$
\mathcal{L}(F, D, \lambda)=r^{f} \cdot F-r^{d} \cdot D+\lambda \cdot(\rho \cdot D+\chi \cdot I-F)
$$

After Equation 4 is solved, we have an optimum rate of financing to achieve maximum profit at a given rate of financing (i.e., the profit and loss sharing rate):

$$
r_{i}^{f}=r_{k}^{d} \cdot\left(\frac{D_{k}}{x-I}+\frac{D_{k}}{F_{i}}\right)
$$

Equation 5 states that the optimum financing rate is the function of the deposit rate based upon two sources. The first deposit source is from other investment or charitable Islamic ethics funding such as zakat, waqf, infaq, or sadaqah; this is called Maqasid deposit. The second is a deposit from Islamic bank customers, such as wadiah. The financing rate is also strongly associated with risk factors that are covered in the deposit function, given by:

$$
r_{i}^{f} \cdot \chi=r_{k}^{d} \cdot\left(\frac{D_{k}}{I}+\frac{D_{k}}{F_{i}}\right)
$$

Equation 6 states that financing costs are equal to the cost of input such as deposits from other investments (I) and charitable Islamic ethics such as zakat, waqf, and sadaqah $(\mathrm{Fi})$. The optimal rate of financing is defined as:

$$
r_{i}^{f} \cdot \chi-r_{k}^{d} \cdot\left(\frac{D_{k}}{I}+\frac{D_{k}}{F_{i}}\right)=0
$$

Equation 7 informs us that financing equilibrium is associated with a risk factor of $\chi$ where the increase in the financing rate directly affects an increase in risk. The risk factor is the exogenous variable which Islamic banks are unable to control. We can distinguish risk into controlled risk $(\bar{\zeta})$ and uncontrolled risk $(1-\zeta)$ as a probability of unity distribution that defines $\chi=(1-\zeta)$.

$$
r_{i}^{f}(1-\zeta)=r_{k}^{d} \cdot\left(\frac{D_{k}}{I}+\frac{D_{k}}{F_{i}}\right)=r_{i}^{f}-r_{i}^{f} \cdot \zeta=r_{k}^{d} \cdot\left(\frac{D_{k}}{I}+\frac{D_{k}}{F_{i}}\right)
$$

Equation 8 demonstrates that the cost of financing in the Islamic banking sector is a subtract function between the cost of financing, cost of deposit, and cost of mitigation risk according to risk characteristics. Finally, we get the complete equation of optimal financing rate as follows:

$$
r_{i}^{f}=r_{i}^{f} \cdot \zeta+r_{k}^{d} \cdot\left(\frac{D_{k}}{I}+\frac{D_{k}}{F_{i}}\right)
$$

Equation 9 states that the financing rate in Islamic banks is the function of the risk premium rate $(\bar{\zeta})$ associated with the controlled exogenous risk factor and deposit rate associated with the costs of investment and deposits. This equation implies that Islamic bank financing is affected by risk management and deposit collection. Both risk factors and deposit rate followed constant return technology where these variables have a monotonic behavior that affects financing. 
Table 1. Maqasid al-Shari'ah dimension mapping based on the production function approach.

\begin{tabular}{|c|c|c|c|}
\hline $\begin{array}{l}\text { Banking } \\
\text { Production }\end{array}$ & Maqasid al-Shari'ah Indicators & $\begin{array}{c}\text { Dimension in the Maqasid } \\
\text { al-Shari'ah Index }\end{array}$ & E-S-G \\
\hline \multirow{7}{*}{$\begin{array}{l}\text { Output-Q } \\
\text { (6 Indicators) }\end{array}$} & 1-1. Investment in Mudharabah, Musharakah & [1] faith & $\mathrm{S}$ \\
\hline & 3-1. Financing for small and medium enterprises & {$[3]$ self } & $\mathrm{S}$ \\
\hline & $\begin{array}{l}\text { 6-1. Financing for vulnerable sectors such as } \\
\text { agriculture }\end{array}$ & [6] social entity & $\mathrm{E}$ \\
\hline & $6-2$. Financing for clean water & [6] social entity & $\mathrm{E}$ \\
\hline & 6-3. Financing for affordable housing & [6] social entity & $\mathrm{E}$ \\
\hline & 3-2. Inclusive financing & {$[3]$ self } & $\mathrm{S}$ \\
\hline & 8-1. Financing for renewable energy & [8] environment (ecology) & $\mathrm{S}$ \\
\hline \multirow{12}{*}{$\begin{array}{l}\text { Process-P } \\
\text { (12 Indicators) }\end{array}$} & $\begin{array}{l}\text { 1-4. Vision and mission statements related to } \\
\text { shari'ah principles }\end{array}$ & [1] faith & $\mathrm{S}$ \\
\hline & 2-1. Disclosure of financial reports & {$[2]$ human } & G \\
\hline & 5-1. Benefits for workers & {$[5]$ prosperity } & $\mathrm{S}$ \\
\hline & 5-2. Number of employees & [5] prosperity & $\mathrm{S}$ \\
\hline & $\begin{array}{l}\text { 2-2. Compliance with Islamic Financial Services } \\
\text { Board }\end{array}$ & {$[2]$ human } & G \\
\hline & 2-3. Shari'ah governance transparency & {$[2]$ human } & $\mathrm{G}$ \\
\hline & 2-4. Transparency standard & {$[2]$ human } & $\mathrm{S}$ \\
\hline & 2-5. Company ethics committee & {$[2]$ human } & $\mathrm{S}$ \\
\hline & $\begin{array}{l}\text { 4-1. Involvement in international Islamic } \\
\text { conferences }\end{array}$ & [4] mind & $\mathrm{S}$ \\
\hline & 5-2. Paying tax & [5] prosperity & G \\
\hline & 5-3. Paying dividends & [5] prosperity & G \\
\hline & 8-2. Publish sustainability report & [8] environment (ecology) & $\mathrm{S}$ \\
\hline \multirow{8}{*}{$\begin{array}{l}\text { Input-I } \\
\text { (8 Indicators) }\end{array}$} & 2. Profit and loss sharing & [2] human & $\mathrm{S}$ \\
\hline & 4-2. Research expenditure & [4] mind & $\mathrm{E}$ \\
\hline & 4-3. Promotion cost/ Total expenditure & [4] mind & $\mathrm{E}$ \\
\hline & 5-1. Personnel Expense & {$[5]$ prosperity } & $\mathrm{S}$ \\
\hline & 7-1. Waqf & [7] wealth & $\mathrm{S}$ \\
\hline & 7-2. Sadaqah & {$[7]$ wealth } & $\mathrm{S}$ \\
\hline & 7-3. Qard Hassan/Grants & {$[7]$ wealth } & $\mathrm{S}$ \\
\hline & 7-4. Zakat and Infaq & {$[7]$ wealth } & $\mathrm{S}$ \\
\hline
\end{tabular}

Equation 9 is an Islamic bank production function that portrays input and output activities. It also portrays activities across the heterogeneity of Islamic banks where output is Maqasid financing that is affected by financial performance (i.e., input) and risk mitigation behavior (i.e., process). This behavior is depicted in Equation 9 and the

indicators are detailed Table 1. The input consists of terms $r_{k}^{d} \cdot\left(\frac{D_{k}}{I}\right)$, which are variables that engage with Islamic

ethics investment and other term investments, whereas the terms $r_{k}^{d} \cdot\left(\frac{D_{k}}{F_{i}}\right)$ are the customer deposits of Islamic banks.

In comparison, risk factors that affect the process index will reduce Islamic banks' compliance with the process index, as noted in Table 1. We depicted this process through controlled risk terms of $\left(r_{i}^{f} \cdot \bar{\zeta}\right)$. The controlled risk factor is defined as composite risks, which is the process index that produces more activity to mitigate the risk and improve Maqasid financing. Islamic banks improve efficiency and expand Maqasid financing. When the process index in Table 1 improves, Islamic banks directly comply with risk mitigation procedures and reduce the cost of 
mitigation. Otherwise, when the process index decreases, Islamic banks increase the cost of mitigation and decrease their efficiency.

We argue that Islamic banks' ability to minimize risk is affected by various risks, such as geographical risk, economic risk, or financial risk. When the risks increase, the ability of Islamic banks to improve the process index will decrease. When Islamic banks improve the cost of mitigation, the process index of good governance, social engagement, and other activities are hard to achieve and reduce efficiency. The equation is as follows:

$$
r_{i}^{f} \cdot \zeta=f\left(\rho_{n}\right)<0
$$

Equation 10 states that the process index negatively correlates with $\rho$ as the mitigating risk factors or activities. The controlled risk factors consist of geographical, economic, and financial risks. It is assumed that these factors have a sub-behavioral equation that determines the risk indicators, and when these risk indicators are classified into three categories we get:

$$
r_{i}^{f} \cdot \zeta=\rho_{n}=-\left(\rho_{g}+\rho_{\theta}+\rho_{f}\right) n \in\{g, e, f\}
$$

Equation 11 expresses that aggregated risk indicators, or $\rho_{n}$ as a process index, are determined by geographical risk $\left(\rho_{g}\right)$, economic risk $\left(\rho_{e}\right)$, and financial risk $\left(\rho_{f}\right)$. These risk factors have sub-behavioral function effects for each risk. We estimate the geographical risk $\left(\rho_{g}\right)$ based on geographical factors such as tropical zone, continent location, oil resource abundance, war or conflict, and shari'ah system to improve risk outside of process risk. These factors were separated out because geographical risk is hard to mitigate due to factors that are difficult or impossible to control.

Economic risk $\left(\rho_{e}\right)$ consists of variables that close with Islamic banks activities, such as net interest margin, that proxies how banks respond to the margin between risk premium (i.e., central bank interest rate) and Islamic bank interest rate. We argue that risk premium as a monetary policy imposed by the central bank will hamper the banking industry, affecting the banks' net interest margins (NIM). Financial risk $\left(\rho_{f}\right)$ consists of the Altman z-score for bank bankruptcy and return on equity (ROE) as the ability of the bank to produce equity from the returns that assist Islamic banks in reducing the cost of capital. Charitable funding improvements that reduce the process index as part of the attractiveness of Islamic banks is trusted by the Islamic society to distribute these charitable funds accordingly. Therefore, we have a simultaneous equation function as follows:

$$
r_{i}^{f}=-r_{i}^{f} \cdot \zeta+r_{k}^{d}\left(\frac{D_{k}}{I}\right)+r_{k}^{d}\left(\frac{D_{k}}{F_{i}}\right) ;-r_{i}^{f} \cdot \zeta=-\left(\rho_{g}+\rho_{\theta}+\rho_{f}\right)
$$

Equation 12 has simultaneous functions that mimic the behavior of Maqasid financing in Islamic banks determined by simultaneous behavior of Maqasid financing and the process index. Equation 12 also supports our research objective that the difference in the increase of geographic risk $\left(\rho_{g}\right)$ affects composite risk. 


$$
r_{i}^{f}=-r_{i}^{f} \cdot \zeta+r_{k}^{d}\left(\frac{D_{k}}{I}\right)+r_{k}^{d}\left(\frac{D_{k}}{F_{i}}\right) ;-r_{i}^{f} \cdot \zeta=-\left(\rho_{g}+\rho_{\theta}+\rho_{f}\right)
$$

In Equation 13, we decompose risk $\left(-r_{i}^{f} \cdot \bar{\zeta}\right)$ into two major factors-economic and finance, and geographical

factors. These factors are treated as exogenous factors in the equation. We draw the geographical factors from composite factors into the control variable to measure the magnitude of the factors. We can then explore each geographical location that proxies the dummy variable effect on Maqasid financing. Hence, we get:

$$
r_{i}^{f}=-\rho_{g}^{\rho}-\rho_{\theta_{i} f}^{\rho}+r_{k}^{d}\left(\frac{D_{k}}{I}\right)+r_{k}^{d}\left(\frac{D_{k}}{F_{i}}\right) ; \mathrm{P}_{\theta_{i} f}^{\rho}=-\left(\rho_{e}+\rho_{f}\right)
$$

Furthermore, each variable in Equation 14 is proxied into the equation as given by:

$$
r_{i}^{f}=-\delta_{g . \text { East }}^{\rho} \cdot D_{g \cdot \text { East }}^{\rho}-\delta_{g . \text { Oil }}^{\rho} \cdot D_{g \cdot \text { OUI }}^{\rho}-\mathrm{P}_{\text {e.f }}^{\rho}+r_{k}^{d}\left(\frac{D_{k}}{I}\right)+r_{k}^{d}\left(\frac{D_{k}}{F_{i}}\right)
$$

where $\mathrm{P}_{\theta, f}^{\rho}=-\left(\rho_{e}+\rho_{f}\right)$.

Equation 15 demonstrates that the cost of financing portrayed in Maqasid financing is the minus function of geographical risk of eastern locations, the geographical risk of oil, and aggregated risk indicators, plus the cost of other investments and the cost of ethical Islamic deposits. The first geographical variable is eastern location. As previous studies such as Jawadi et al. (2017) stated, Islamic banks in eastern locations positively affect Islamic bank performance. We assume that a country located in an eastern region is riskier than a non-eastern region to expand Maqasid financing. Countries such as Indonesia and Malaysia are secular countries where Islamic banking is difficult to grow. The existence of monetary and banking systems still relies on conventional banking rather than in Middle East countries where the majority apply Islamic shari'ah law. Therefore, expanding Maqasid financing will be difficult in eastern regions, whereas expanding Maqasid financing will be easier in the Middle East.

The second geographical variable is the location of oil producers. A previous study by Imam \& Kpodar (2016) stated that regions that are abundant in oil resources positively correlate with Islamic financial development, but production was halted after 9/11. It is assumed that oil-producing countries are riskier than non-oil-producing countries for expanding Maqasid financing. The countries with larger oil producers have various hindrances to financial development due to global war or conflict that reduces the expansion of Maqasid financing. The geopolitics in these regions will also promote uncertainties regarding the development of Maqasid financing. After political turmoil, achieving Maqasid financing in the short term will be difficult, as the respective banks are the governments' banks. Despite this, Islamic banks prefer commercial motives rather than Maqasid financing motives (Budiman et al., 2021).

\section{DATA AND METHODS}

The database consists of macro and micro data retrieved from the Prudential and Structural Islamic Financial Indicators (PSIFIs) from the Islamic Financial Services Board (IFSB) containing quarterly data from Q4 2013 to Q3 2020. We collected financial performance data from the IFSB. The data includes countries such as Afghanistan, Bahrain, Bangladesh, Brunei Darussalam, Egypt, Indonesia, Iran, Jordan, Kazakhstan, Kuwait, Lebanon, Malaysia, Nigeria, Oman, Pakistan, Palestine, Qatar, Saudi Arabia, Sudan, Turkey, the United Arab Emirates, and the United Kingdom. The number of countries was reduced to ten due to the availability and consistency requirements for 
estimation. These ten countries are: Bangladesh, Brunei Darussalam, Indonesia, Iran, Jordan, Kazakhstan, Malaysia, Oman, Pakistan, and the United Arab Emirates.

The first macro data for the endogenous variable for Maqasid financing in maqasid sectors is the share of financing for agriculture, water, science, social, health, and household sectors. The maqasid sectors are referred to as total financing. The geographical data is based upon location according to Google maps for the eastern dummy and the dummy for oil producers based on the descriptions on the Organization of the Petroleum Exporting Countries (OPEC) official website (www.opec.org). The other areas of macro data are net interest income (NII), the cost to income, and non-profit margin (NPM), which were retrieved from the IFSB database from Q1 2012 to $\mathrm{Q}^{4}$ 2019. The microdata used comprises zakat, qard hassan, wadiah, other shari'ah charity, and sustainability activity indicators, such as the Corporate Social Responsibility (CSR) Index and the Financial Disclosure Report Index (FDRI). We retrieved these data from Thomson Reuters Islamic Financial Development Indicators (IFDI) database for 159 Islamic banks across ten predominantly Muslim countries from 2013 to 2019. We directly used CSR and FDRI from the IFDI by creating scores between $0-100$, whereas, for each sub-index of CSR and FDRI, we gathered and equally distributed the weight. Since the macro data is quarterly, we combined these datasets into quarterly data according to the approach taken by Meijering (2002).

We estimated a modified Z-score according to Cihák \& Hesse (2010), which is $z=\frac{k+\mu}{\sigma}$, where $\mathrm{k}$ is equity of capital and reserve as a percent of assets, $\boldsymbol{\mu}$ is the average return as a percent of assets, and $\sigma$ is the standard deviation of return on assets as a proxy of return volatility. We retrieved return on assets (ROA) and equity of capital data from the IFDI Thomson Reuters dataset for 159 Islamic banks. We calculated $\sigma$ by estimating the standard deviation for each Islamic bank across the period and aggregated it with the average of all Islamic banks. The descriptive data for the variables are depicted in Table 2.

\subsection{Methods}

While the profiles of Islamic bank countries were discussed, to meet research objectives we analyzed the differences of each variable in Equation 12 with quantile regression estimation.

This analysis was applied to depict the differences in Maqasid financing expansion of different countries on exogenous factors affected by input and control of the process index and its sub-behavioral variables.

On the other hand, Equation 12 is a simultaneous function that uses a two-stage least squares (2SLS) estimation or instrument variable (IV) estimation. In contrast, the exogenous factors with different data distribution effects are geographical, economic, and financial risk factors. 
Asian Economic and Financial Review, 2022, 12(2): 70-88

\begin{tabular}{l|c|c|c|c|c|c|c|c|c|c|c}
\hline Country & $\begin{array}{c}\text { No. of } \\
\text { Banks }\end{array}$ & Maqasid Financing & D East & D Oil & NIM & Process Index & ZQO & ROA & Z-Score & ROE & Wadiah \\
\hline Bangladesh & 22 & $4.12 \%$ & 0 & 0 & 2.257 & 45.530 & 0.600 & 0.015 & 6.886 & 0.241 & 170,122 \\
\hline Brunei & 1 & $13.89 \%$ & 1 & 0 & 0.013 & 39.475 & 0.000 & 0.016 & 25.524 & 0.120 & 24,715 \\
\hline Indonesia & 29 & $6.40 \%$ & 1 & 0 & 1.334 & 46.952 & 0.600 & 0.012 & 12.072 & 0.121 & 32,986 \\
\hline Iran & 25 & $9.13 \%$ & 0 & 1 & 1.345 & 37.586 & 0.433 & 0.014 & 29.170 & 0.131 & $2,713,539$ \\
\hline Jordan & 3 & $0.90 \%$ & 0 & 0 & 0.006 & 64.492 & 0.833 & 0.018 & 21.666 & 0.184 & 1,938 \\
\hline Kazakhstan & 1 & $8.22 \%$ & 0 & 0 & 128.715 & 30.354 & 0.000 & 0.018 & 5.702 & 0.052 & $8,878,309$ \\
\hline Malaysia & 31 & $4.40 \%$ & 1 & 0 & 0.351 & 51.167 & 0.600 & 0.011 & 16.846 & 0.158 & 70,615 \\
\hline Oman & 8 & $0.20 \%$ & 0 & 0 & 0.297 & 55.017 & 0.467 & -0.018 & 9.962 & -0.014 & 95,055 \\
\hline Pakistan & 21 & $16.25 \%$ & 0 & 0 & 3.023 & 50.991 & 0.533 & 0.012 & 13.866 & 0.184 & 304,285 \\
\hline United Arab Emirates & 18 & $11.60 \%$ & 0 & 1 & 0.463 & 43.177 & 0.467 & 0.014 & 106.748 & 0.110 & 103,976 \\
\hline Total & 159 & $7.90 \%$ & 0.3 & 0.2 & 13.779 & 46.539 & 0.453 & 0.013 & 24.844 & 0.129 & $1,374,536$ \\
\hline
\end{tabular}


Chernozhukov \& Hansen (2008) stated that one of the quantile regression's (QR) most appealing features is its ability to estimate quantile-specific effects that describe the impact of covariates not only on the center but also on the tails of the outcome distribution. The impact of geographical factors on the expansion of Maqasid financing based upon the causal effect of the risk factor on the process index is difficult due to the self-selection risk status.

$$
\begin{aligned}
& r_{i}^{f}=-\delta_{g \cdot \text { East }}^{\rho} \cdot D_{g \cdot E a s t}^{\rho}-\delta_{g \cdot O i l}^{\rho} \cdot D_{g \cdot \text { oul }}^{\rho}-\mathrm{P}_{e_{f} f}^{\rho}+r_{k}^{d}\left(\frac{D_{k}}{I}\right)+r_{k}^{d}\left(\frac{D_{k}}{F_{i}}\right) ; \\
& \mathrm{P}_{\theta_{i} f}^{\rho}=-\left(\rho_{e}+\rho_{f}\right)
\end{aligned}
$$

If we look at Equation 16, the model is estimated with instrumental variables to reduce selection bias in the process index. We should treat this process index as an instrumental variable affected by risk variables, such as economic and financial factors. The empirical model with the IV model is as follows:

$$
r_{i}^{f}=-\delta_{g \cdot \text { East }}^{\rho} D_{g \cdot \text { East }}^{\rho}-\delta_{g \cdot \text { Oil }}^{\rho} D_{g \cdot \text { Oil }}^{\rho}-\gamma_{\mathrm{p}} \mathrm{P}_{\theta_{i} f}^{\rho}+r_{k}^{d} R O A+r_{k}^{d} \ln \text { Wadiah }+\epsilon_{i}
$$

\section{$\mathrm{P}_{\theta_{f} f}^{\rho}=-($ Zakat, Qard Hassan, Waqf, Return on Equity(ROE), Z-Score, Net Interest Margin(NIM))}

Moreover, we extend this equation into IVQR according to Machado \& Santos (2019), and is given as:

$$
\begin{aligned}
& q_{\alpha, i}\left(r_{i}^{f} \mid \Omega_{i}\right)=-\Omega_{1, \alpha} D_{g-E a s t}^{\rho}-\Omega_{2, \alpha} D_{g \cdot \text { Oil }}^{\rho}-\Omega_{a_{\alpha} \alpha} P_{a \cdot f}^{\rho}+\Omega_{4, \alpha} R O A+\Omega_{5, \alpha} \text { Wadiah } \\
& P_{e \cdot f}^{P}=-\left(\text { Zakat }_{v} \text { Qard Hassan, Waqf, Return on Equity(ROE) },\right. \text { Z-Score, Net Interest Margin(NIM)) }
\end{aligned}
$$

Where $\Omega_{i}$ is the quantile parameter for each variable according to Equation 17. In Equation 17, the Islamic banks across countries have selection criteria to internalize financial and economic risk and other control variables over time. The geographical effect for each country will follow a nonlinear function rather than the linear function in Equation 17. The quantile regression employed in Equation 18 can analyze the relationship between geographic and maqasid financing performance. It is assumed that each country has a specific factor that varies among Islamic banks. This time, the variability will show us whether geographical risk and aggregate risk factors (i.e. Process Index) improve financial performance (ROA) and deposits (wadiah) on Maqasid financing.

\section{RESULTS AND DISCUSSION}

The first analysis we describe in this section is estimating Equation 16 with instrumental variable least squares (IVLS) and instrumental variable quantile regression (IVQR). The objective of IVLS estimation is to estimate the geographical factors and sub-behavior of the process index and other instrumental variables' effects on Maqasid financing without detailed environmental factors. The second objective of IVQR estimation is to estimate and confirm whether the first result is robust or not for producing better estimation by assessing various exogenous or instrumental factors on Maqasid financing. Before we move to confirm the research question, we compare Model 1 (without geographical factors) with Model 2 (with geographical factors) to determine which model is better. The Hansen and Basman statistics indicate that both models accept the null hypothesis that there is no overidentification. On the other hand, Model 2 has larger Hansen and Basman p-values than Model 1. These pvalues indicate that Model 2 is better than Model 1 in more minor overidentification problems for estimating 
simultaneous equations. We can therefore confirm that Model 2 is the most appropriate model for estimating simultaneous equations and is ready for hypothesis testing.

The main results in Table 2 column (2) indicate that geographical factors such as the Dummy East location and oil producers negatively affect Maqasid financing (-0.0708) with a 99\% significance level and (-0.102) with a 95\% significance level, respectively. The dummy variable of eastern location confirms an adverse risk of about $7.08 \%$ for expanding Maqasid financing, whereas non-eastern locations are the opposite. This result means that eastern dummy negatively affects the expansion of Maqasid financing, whereas the non-eastern dummy is positive. The empirical model confirms with our theoretical model that the non-eastern regions are suitable for expanding Maqasid financing, whereas the East is not.

The oil production dummy variable negatively affects Maqasid financing. The regions with major oil producers reduces of the expansion of Maqasid financing (-10.2\%); otherwise, non-oil producers go in the opposite direction for Maqasid financing. The empirical model confirmed our theoretical model that the regions of major oil producers harm Maqasid financing, whereas the regions of non-major oil producers do not.

Table 3. Instrumental variable regression of geographic factors

\begin{tabular}{|c|c|c|}
\hline & $(1)$ & $(2)$ \\
\hline Variable & Maqasid Finan & Maqasid Finan \\
\hline \multirow[t]{2}{*}{$\underline{\mathrm{Ln}(\text { Wadiah })}$} & 0.00406 & -0.00505 \\
\hline & $(0.00468)$ & $(0.00722)$ \\
\hline \multirow[t]{2}{*}{$\mathrm{ROA}$} & $0.582^{*}$ & $0.923 * * *$ \\
\hline & $(0.319)$ & $(0.324)$ \\
\hline \multirow[t]{2}{*}{ Process Index } & $-0.118^{* *}$ & $-0.379 * * *$ \\
\hline & $(0.0549)$ & $(0.147)$ \\
\hline \multirow[t]{2}{*}{ Dummy East } & & $-0.0708^{* * * *}$ \\
\hline & & $(0.0220)$ \\
\hline \multirow[t]{2}{*}{ Dummy Oil Prod. } & & $-0.102^{* *}$ \\
\hline & & $(0.0429)$ \\
\hline \multirow[t]{2}{*}{ Constant } & $0.470^{*}$ & $1.624^{* * *}$ \\
\hline & (0.260) & $(0.637)$ \\
\hline Observations & 238 & 238 \\
\hline R-squared & 0.45 & 0.91 \\
\hline Hansen p-value & 0.292 & 0.457 \\
\hline Basman p-value & 0.293 & 0.469 \\
\hline
\end{tabular}

Instrumental variables in the process index are: $\ln$ (zakat + qard hassan + waqf), ROE, Altman Z-Score, $\ln (\mathrm{Net}$ Interest Margin) After geographical variables, another risk variable that strongly relates to geography is the risk process index determined by: $\ln$ (zakat + qard hassan + waqf), ROE, Altman Z-Score, $\ln ($ Net Interest Margin). The process index parameter negatively affects the expansion of Maqasid financing with a 99\% significance level. The improvement of financial risk factors improves the process index to mitigate the risk and reduce expanding Maqasid financing. During the observation period, improving the process index of Maqasid financing is hard for Islamic banks to comply with regarding Islamic ethics. The empirical model supports our theoretical model that the process index negatively affects Maqasid financing. Increasing financial and economic risk factors improve risk process index cost and reduce Maqasid financing.

Another variable that indicates financial performance is proxy by ROA. The increase of ROA increases Maqasid financing by $92.3 \%$, with a $99 \%$ level of significance. Along with other control variables, improving ROA improves Maqasid financing ceteris paribus; there is an intention that Islamic banks conduct Islamic moral economy. Our empirical model confirms the theoretical model that increasing ROA improves Maqasid financing.

The latest variable is the wadiah parameter. Ideally, the results should positively affect Maqasid financing. On the other hand, the results are different from our theoretical model. Wadiah has a negative and insignificant effect 
on Maqasid financing. If we look at the data pattern, wadiah has been declining during the observation period. The analysis suggests that the Islamic banks' production input during the observation period is not basically from a large scale of wadiah consumers that increase customer growth. Wadiah funding is basically from a private or specific group that offers funding to Islamic banks. In addition, Islamic banks' production input increases from investments such as zakat, waqf, qard hassan, and other investment opportunities outside wadiah that we depict in the instrument variable for the process index. Therefore, the cost of this fund will be more expensive or risky than public majority funding, such as personal, small, or medium customers as part of wadiah deposit customers. The empirical results are surprisingly contrary to the theoretical model that wadiah negatively affects Maqasid financing but the effect is insignificant.

The first analysis with 2SLS estimation confirmed that most theoretical variables align with the empirical model, except wadiah. It was proven that geographic factors and most of the variables are statistically significant and have the expected sign. Although our theoretical model is in line with the empirical model, on the other hand, the results do not produce the heterogeneity performance of geographical factors that affect Maqasid financing across countries. Further exploration is needed by estimating Model 2 with IVQR to answer our research question of whether the specific differences of geographical factors affect Maqasid financing and support the previous 2SLS estimation. Although 2SLS estimation produces better model specification, there is a caveat of selection bias on geographic variables. Furthermore, it seems that geographical results are inconclusive. We need to explore specific analyses to ensure the robustness of the results. A similar pattern between Dummy East and Dummy Oil led to selection bias estimation in the 2SLS estimation. Recent research, such as the study by Machado \& Santos (2019), attempts to remedy the selection bias in instrumental regression by conducting moment in instrumental regression.

Moreover, while we analyzed the details of geographic factors by conducting quantile regression, the selection bias in an instrumental variable that can hamper the quantile estimation. Therefore, we estimate Equation 16 by applying IVQR to reduce the lection bias of geographic factors that affect Maqasid financing. According to Machado \& Santos (2019), IVQR can solve this selection bias. This estimation method reduces selection bias and produces robust results. Hence, we can confirm whether the hypothesis is in line with the research question.

The full results of IVQR are presented in Table 4, which depicts the refined results in Table 3 that produce the selection bias results of geographical variables. Table 4 also indicates the quintile threshold of Maqasid financing that demonstrates the effect of exogenous variables on each quintile threshold. The heading row table lists the independent variables, as per Equation 17. We have the quantile classification of the Maqasid financing share from the largest share of data observations towards the smallest share of Maqasid financing. This information is helpful for us to get detailed environmental factors along with which variables have a lesser effect and more of an effect on Maqasid financing expansion. The largest share of Maqasid financing for commercial financing belongs to Pakistan (16.25\%), with the rest listed in descending order: Brunei (13.89\%), UAE (11.6\%), Iran (9.13\%), Kazakhstan (8.22\%), Indonesia (6.4\%), Malaysia (4.4\%), Bangladesh (4.12\%), Jordan (0.9\%), and Oman (0.2\%). These figures provide insight into how geographical factors affect Maqasid financing and the control variables accordingly. The results of the IVQR in Table 4 indicate that the Dummy East geographical factor negatively affects the largest quintile share of Maqasid financing. About $60 \%$ of the top quintile contributes to the most prominent Maqasid financing, such as Kazakhstan towards Pakistan. The countries located in the non-eastern hemisphere have a statistically significant impact on improving Maqasid financing with a 99\% confidence level. Otherwise, the IVQR has eliminated selection bias on dummy oil production that is correlated with Dummy East. When the bias estimation is removed it is confirmed that the dummy variable of oil production does not significantly affect Maqasid financing. We also confirmed that our theoretical model of the geographical risk variable produces robust results rather than without geographical risk variables (see Appendix 1 to compare with Table 4). When geographical variables are applied, the results indicate that risk factors such as the process index become significant in the model. 
Asian Economic and Financial Review, 2022, 12(2): 70-88

Table 4. Instrumental variable quantile regression (IVOR) of geographic factors.

\begin{tabular}{|c|c|c|c|c|c|c|c|c|c|}
\hline & $\overline{(0.1)}$ & $\overline{(0.2)}$ & $\overline{(0.3)}$ & $(0.4)$ & $\overline{(0.5)}$ & $(0.6)$ & $\overline{(0.7)}$ & $(0.8)$ & $\overline{(0.9)}$ \\
\hline Variable & $\begin{array}{l}\text { Maqasid } \\
\text { Finan }\end{array}$ & $\begin{array}{l}\text { Maqasid } \\
\text { Finan }\end{array}$ & $\begin{array}{l}\text { Maqasid } \\
\text { Finan }\end{array}$ & $\begin{array}{l}\text { Maqasid } \\
\text { Finan }\end{array}$ & $\begin{array}{c}\text { Maqasid } \\
\text { Finan }\end{array}$ & $\begin{array}{l}\text { Maqasid } \\
\text { Finan }\end{array}$ & $\begin{array}{l}\text { Maqasid } \\
\text { Finan }\end{array}$ & $\begin{array}{l}\text { Maqasid } \\
\text { Finan }\end{array}$ & $\begin{array}{c}\text { Maqasid } \\
\text { Finan }\end{array}$ \\
\hline \multirow[t]{2}{*}{ Ln(Wadiah) } & 0.00116 & 0.00505 & 0.00863 & $0.0122 * *$ & $0.0158^{* * * *}$ & $0.0217^{* * * *}$ & $0.0268^{* * *}$ & $0.0389^{* * *}$ & $0.0563^{* * * *}$ \\
\hline & $(0.00674)$ & $(0.00608)$ & $(0.00554)$ & $(0.00511)$ & $(0.00486)$ & $(0.00474)$ & $(0.00557)$ & $(0.00776)$ & $(0.0116)$ \\
\hline \multirow[t]{2}{*}{$\mathrm{ROA}$} & $1.198^{*}$ & $1.101^{*}$ & 1.012 & 0.924 & 0.833 & 0.686 & 0.560 & 0.258 & -0.175 \\
\hline & $(0.701)$ & $(0.650)$ & $(0.621)$ & $(0.611)$ & $(0.620)$ & $(0.676)$ & $(0.758)$ & $(1.025)$ & $(1.490)$ \\
\hline \multirow[t]{2}{*}{ Process Index } & $-0.0285^{* * *} *$ & $-0.0247^{* * * *}$ & $-0.0212^{* * * *}$ & $-0.0177^{* *}$ & -0.0141 & -0.00838 & -0.00341 & 0.00842 & 0.0254 \\
\hline & $(0.00730)$ & $(0.00706)$ & $(0.00759)$ & $(0.00870)$ & (0.0103) & (0.0133) & $(0.0164)$ & $(0.0238)$ & $(0.0348)$ \\
\hline \multirow[t]{2}{*}{ Dummy East } & 0.00626 & -0.00107 & -0.00783 & -0.0145 & -0.0214 & $-0.0325^{* * *}$ & $-0.0421^{* * *}$ & $-0.0649^{* * *}$ & $-0.0977^{*} * *$ \\
\hline & $(0.0226)$ & $(0.0207)$ & $(0.0192)$ & $(0.0179)$ & $(0.0170)$ & $(0.0161)$ & $(0.0169)$ & $(0.0207)$ & $(0.0297)$ \\
\hline \multirow[t]{2}{*}{ Dummy Oil Prod. } & 0.00830 & 0.00479 & 0.00155 & -0.00165 & -0.00493 & -0.0103 & -0.0148 & -0.0258 & -0.0415 \\
\hline & $(0.0541)$ & $(0.0486)$ & $(0.0436)$ & (0.0389) & $(0.0344)$ & $(0.0281)$ & $(0.0245)$ & $(0.0259)$ & $(0.0455)$ \\
\hline \multirow[t]{2}{*}{ Constant } & 0.101 & 0.0577 & 0.0181 & -0.0212 & -0.0613 & $-0.127 * *$ & $-0.183^{*} *$ & $-0.317 * * *$ & $-0.509^{* * * *}$ \\
\hline & $(0.0686)$ & $(0.0606)$ & $(0.0554)$ & $(0.0531)$ & $(0.0549)$ & $(0.0635)$ & $(0.0802)$ & $(0.121)$ & $(0.183)$ \\
\hline Observations & 238 & 238 & 238 & 238 & 238 & 238 & 238 & 238 & 238 \\
\hline
\end{tabular}

Note: Standard errors in parentheses: **** $\mathrm{p}<0.01{ }^{*} * \mathrm{p}<0.05,{ }^{*} \mathrm{p}<0.1$. Instrument variables on the process index variable: $\ln (\mathrm{zakat}+$ qard hassan + waqf), ROE, Altman Z-Score, In(Net Interest Margin). 
This Dummy East variable confirms the hypothesis that countries in the non-eastern region, such as the Middle East or southern regions, have a significant impact on Maqasid financing. Looking at the geopolitical system, most of these regions comply with shari'ah law and support the Islamic system that exists in the economy. Directly, this system will promote Islamic finance for Maqasid financing. In comparison, eastern regions, such as Indonesia, Malaysia, Bangladesh, Jordan, and Oman, have a more negligible effect on Maqasid financing. We proved that geographical factors affect Maqasid financing, and therefore our hypothesis is confirmed.

The process index variable that mitigates process risk for an Islamic bank in the lowest quintile of Maqasid financing has a negative effect and is statistically significant on the expansion of Maqasid financing rather than the highest quintile. The risk factor affects the lowest quintile of Maqasid financing and is more significant than in the highest quintile. The Islamic bank with the lowest quintile of Maqasid financing is riskier than commercial financing and prefers commercial financing. The sign is as expected when Islamic banks adopt more process index variables that indicate the highest quintile ( $80 \%$ and $90 \%)$, although they are not statistically significant. This result confirms the finding by Scholtens \& van't Klooster (2019) that conducting Maqasid financing reduces the risk and improves sustainable financing performance. However, our results are not statistically significant.

Other variables that portray financial performance, such as ROA, confirmed that Islamic banks with the lowest quintile of Maqasid financing have a positive and statistically significant effect on ROA than the highest quintile of Maqasid financing. The results indicate that most countries with the highest quintile of Maqasid finance cannot improve financial performance due to risk mitigation. It is claimed that this phenomenon exists because Islamic banks in Indonesia, Malaysia, Bangladesh, and other regions with the lowest Maqasid financing prefer commercial financing and countries with less shari'ah law. When commercial financing is preferable, risk mitigation in Islamic banks is less risky than Maqasid financing. Islamic banks should be able to compete with conventional banks and survive in the financial market. This condition is confirmed by Albaity et al. (2019), who stated that Islamic banks have a fragility effect on the competition with a conventional bank when the banking system in a country is not governed by shari'ah law. Islamic banks find it difficult to compete with conventional banks.

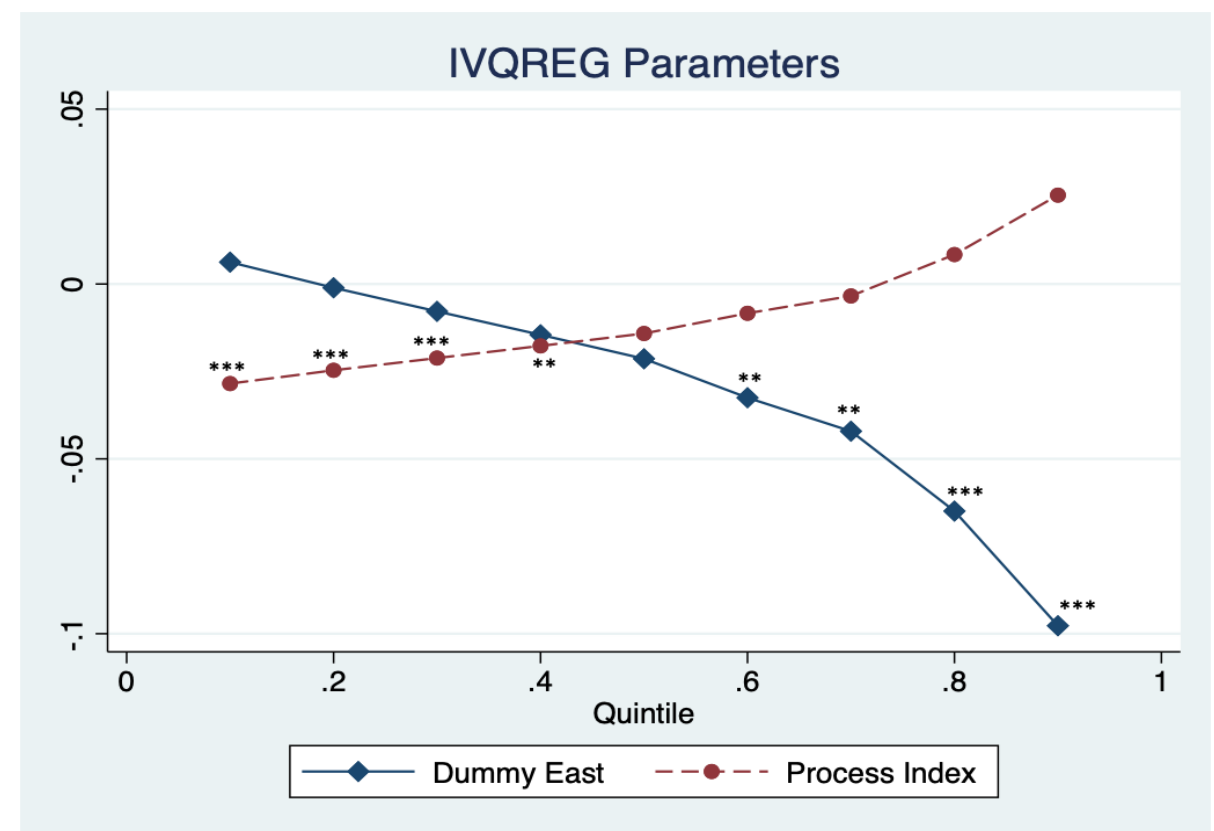

Figure 1. Parameter transition of dummy east and process index variables.

Note: Significance level: ${ }^{* * *} \mathrm{p}<0.01,{ }^{*} * \mathrm{p}<0.05,{ }^{*} \mathrm{p}<0.1$.

The last variable is wadiah. The results confirm that the highest quintile of Maqasid financing is positive and statistically significant on the expansion of Maqasid financing, whereas the lowest is not. This result is confirmed by our theoretical model that increasing wadiah capacity increases Maqasid financing. These empirical results 
support our theoretical model and confirm previous results that geographical factors improve wadiah due to the shari'ah system in the country.

In order to get a picture of how the IVQR parameters affect quintile intervals, we depicted the Dummy East and process index parameters in Figure 1. This figure illustrates two relationships between two variables: quintile parameters in the horizontal line and the parameter effect (i.e., Dummy East and Process Index) of the model in a vertical line. The relationships demonstrate in which quintile the parameter has the expected sign and is close to our theoretical model.

Figure 1 demonstrated that the process index parameter increased and lost statistical significance and went from $99 \%$ to $95 \%$. There is a decrease in the Dummy East parameter and its statistical significance improved from 95\% to $99 \%$. This graph confirms that non-eastern areas (i.e., Middle East) that relates to the countries with solid shari'ah law have a lowered process index, which decreases significantly due to regional tension and economic development. This graph confirms the findings of Albaity et al. (2019), that national political interest is crucial for Islamic banks to compete with a conventional bank.

\section{CONCLUSION}

It was concluded that our empirical model is close to our theoretical model and that geographical factors positively affect Maqasid financing. Other variables, such as wadiah and process index, are in line with our theoretical model. For ROA, the results do not satisfy our theoretical model. We claimed that Islamic shari'ah law is essential to promote Islamic finance. Geopolitical factors that support the Islamic shari'ah platform is a crucial factor to promote Maqasid financing. When the shari'ah law in a country is less intense, the Islamic banks prefer commercial financing over Maqasid financing due to the competition with a conventional bank.

In terms of shari'ah law, it seems that applying this law globally would not be the only way. Shari'ah law is a coherence for an Islamic society to comply with his/her religious ways without state intervention. The increasing Islamic literacy among Muslims will increase the need for Islamic finance and force Islamic banks into sustainability. We suggest that Islamic society strongly supports Sustainable Development Goals (SDGs), similar to Islamic ethics. Unfortunately, the development process in our observation countries has different environmental factors. We recommend that an international organization should support and promote an initiative to help Islamic banks achieve SDGs. International collaboration can improve Islamic banks' compliance with Islamic ethics to support SDGs.

In terms of method, this paper has proved that IVQR is the proper tool to reduce selection bias in the model and produces robust estimation results. For future research, we recommend more data frequency, and the Islamic bank database can validate our results, especially the banking system, which can produce exciting results with this model. This investigation will also assist us in answering questions regarding whether the variables associated with shari'ah law are in concordance with Islamic banks' financial development across countries.

Funding: This study received no specific financial support.

Competing Interests: The authors declare that they have no competing interests.

Authors' Contributions: All authors contributed equally to the conception and design of the study.

\section{REFERENCES}

Acemoglu, D., Johnson, S., \& Robinson, J. A. (2002). Reversal of fortune: Geography and institutions in the making of the modern world income distribution. The Quarterly Journal of Economics, 117(4), 1231-1294. Available at: https://doi.org/10.1162/003355302320935025.

Ahmed, H., Mohieldin, M., Verbeek, J., \& Aboulmagd, F. (2015). On the sustainable development goals and the role of Islamic finance. World Bank Policy Research Working Paper, No. (7266). 
Akhtar, M. R. (2000). Poverty alleviation on a sustainable basis in the islamic framework. The Pakistan Development Review, 39(4), 631-647. Available at: https://doi.org/10.30541/v39i4iipp.631-647.

Albaity, M., Mallek, R. S., \& Noman, A. H. M. (2019). Competition and bank stability in the MENA region: The moderating effect of Islamic versus conventional banks. Emerging Markets Review, 38(January), 310-325. Available at: https://doi.org/10.1016/j.ememar.2019.01.003.

Aliyu, S., Hassan, M. K., Mohd, Y. R., \& Naiimi, N. (2017). Islamic banking sustainability: A review of literature and directions for future research. Emerging Markets Finance and Trade, 53(2), 440-470. Available at: https://doi.org/10.1080/1540496X.2016.1262761.

Beck, T., Demirgüç-Kunt, A., \& Merrouche, O. (2013). Islamic vs. conventional banking: Business model, efficiency and stability. Journal of Banking and Finance, 37(2), 433-447. Available at: https://doi.org/10.1016/j.jbankfin.2012.09.016.

Bedoui, H. E., \& Mansour, W. (2015). Performance and Maqasid al-Shari'ah's pentagon-shaped ethical measurement. Science and Engineering Ethics, 21(3), 555-576. Available at: https://doi.org/10.1007/s 11948-014-9561-9.

Boyd, J. H., \& Nicolo, D. G. (2005). The theory of bank risk taking and competition revisited. The Journal of Finance, 60(3), 13291343. Available at: https://doi.org/10.1111/j.1540-6261.2005.00763.x.

Budiman, T., Satyakti, Y., \& Febrian, E. (2021). Islamic bank sustainability: An econometric approach. Asian Economic and Financial Review, 11(2), 141-159. Available at: https://doi.org/10.18488/JOURNAL.AEFR.202 1.112.141.159.

Chernozhukov, V., \& Hansen, C. (2008). Instrumental variable quantile regression: A robust inference approach. Journal of Econometrics, 142(1), 379-398. Available at: https://doi.org/10.1016/j.jeconom.2007.06.005.

Cihák, M., \& Hesse, H. (2010). Islamic banks and financial stability: An empirical analysis. Journal of Financial Services Research, 38, 95-113. Available at: https://doi.org/10.1007/s10693-010-0089-0.

Çizakça, M. (2014). Risk sharing and risk shifting: An historical perspective. Borsa Istanbul Review, 14(4), 191-195. Available at: https://doi.org/10.1016/j.bir.2014.06.001.

Freixas, X., \& Rochet, J.-C. (2009). The microeconomics of banking (2nd ed. Vol. 85). Cambridge, Massachusetts: MIT Press.

Imam, P., \& Kpodar, K. (2016). Islamic banking: Good for growth? Economic Modelling, 59, 387-401. Available at: https://doi.org/10.1016/j.econmod.2016.08.004.

Jawadi, F., Jawadi, N., Cheffou, A. I., Ameur, H. B., \& Louhichi, W. (2017). Modelling the effect of the geographical environment on Islamic banking performance: A panel quantile regression analysis. Economic Modelling, 67, 300-306. Available at: https://doi.org/10.1016/j.econmod.2017.01.018.

Jawadi, F., Jawadi, N., Ameur, B. H., \& Idi, C. A. (2017). Does Islamic banking performance vary across regions? A new puzzle. Applied Economics Letters, 24(8), 567-570. Available at: https://doi.org/10.1080/13504851.2016.1210764.

Lensink, R., Meesters, A., \& Naaborg, I. (2008). Bank efficiency and foreign ownership: Do good institutions matter? Journal of Banking and Finance, 32(5), 834-844. Available at: https://doi.org/10.1016/j.jbankfin.2007.06.001.

Machado, J. A. F., \& Santos, S. J. M. C. (2019). Quantiles via moments. Journal of Econometrics, 213(1), 145-173. Available at: https://doi.org/10.1016/j.jeconom.2019.04.009.

Meijering, E. (2002). A chronology of interpolation: From ancient astronomy to modern signal and image processing. Proceedings of the IEEE, 9O(3), 319-342. Available at: https://doi.org/10.1 109/5.993400.

Mergaliyev, A., Asutay, M., Avdukic, A., \& Karbhari, Y. (2021). Higher ethical objective (Maqasid al-Shari'ah) augmented framework for Islamic banks: Assessing ethical performance and exploring its determinants. Journal of Business Ethics, 170(4), 797-834. Available at: https://doi.org/10.1007/s10551-019-04331-4.

Platonova, E., Asutay, M., Dixon, R., \& Mohammad, S. (2016). The impact of corporate social responsibility disclosure on financial performance: Evidence from the GCC islamic banking sector. Journal of Business Ethics, 1-21. Available at: https://doi.org/10.1007/s10551-016-3229-0.

Sachs, J. (2000). Tropical underdevelopment (Vol. 3): National Bureau of Economic Research.

Satyakti, Y., Herwany, A., Wardhana, W., \& Pamungkas, E. (2017). Modeling for improving micro finance access in rural area. Paper presented at the ICIRST Conference. 
Scholtens, B., \& Dam, L. (2007). Banking on the equator. Are banks that adopted the equator principles different from nonadopters? World Development, 35(8), 1307-1328. Available at: https://doi.org/10.1016/j.worlddev.2006.10.013.

Scholtens, B., \& van't Klooster, S. (2019). Sustainability and bank risk. Palgrave Communications, 5(1), 1-8. Available at: https://doi.org/10.1057/s41599-019-0315-9.

Scholtens, B. (2017). Why finance should care about ecology. Trends in Ecology and Evolution, 32(7), 500-505. Available at: https://doi.org/10.1016/j.tree.2017.03.013.

Wu, M. W., \& Shen, C. H. (2013). Corporate social responsibility in the banking industry: Motives and financial performance. Journal of Banking and Finance, 37(9), 3529-3547. Available at: https://doi.org/10.1016/j.jbankfin.2013.04.023.

Zulkhibri, M., \& Ismail, A. G. (2017). Financial inclusion and poverty alleviation: Perspectives from Islamic institutions and instruments: Springer.

Appendix: Derivation of the Model

$$
\begin{aligned}
& \mathcal{L}(F, D, \lambda)=r^{f} \cdot F-r^{d} \cdot D+\lambda \cdot(\rho \cdot D+\chi \cdot I-F) \\
& \frac{\partial \mathcal{L}}{\partial F}=r^{f}+\lambda=\lambda=r^{f} \\
& \frac{\partial \mathcal{L}}{\partial D}=-r^{d}+\lambda \cdot \rho=\lambda=\frac{r^{d}}{\rho} \\
& \frac{\partial \mathcal{L}}{\partial \lambda}=\rho \cdot D+\chi \cdot I-F=\rho=\frac{F-\chi \cdot I}{D} \\
& r^{f}=r^{d} \cdot\left[\frac{F-\chi \cdot I}{D}\right]^{-1} \\
& r^{f}=r^{d} \cdot\left[\frac{F}{D}\right]^{-1}+r^{d} \cdot\left[\frac{X^{*} I}{D}\right]^{-1} \\
& r^{f}-\left(r^{d} \cdot D \cdot(\chi \cdot I)^{-1}+(F)^{-1}\right)=0 \\
& r^{f}=r^{d} \cdot\left(\frac{D}{\chi \cdot I}+\frac{D}{F}\right)
\end{aligned}
$$


Appendix 1. Instrumental variable quantile regression (IVQR) without geographic factors.

\begin{tabular}{|c|c|c|c|c|c|c|c|c|c|}
\hline & $(0.1)$ & $(0.2)$ & $(0.3)$ & $(0.4)$ & $(0.5)$ & $(0.6)$ & $(0.7)$ & $(0.8)$ & $(0.9)$ \\
\hline Variable & $\begin{array}{c}\text { Maqasid } \\
\text { Finan }\end{array}$ & $\begin{array}{c}\text { Maqasid } \\
\text { Finan }\end{array}$ & $\begin{array}{l}\text { Maqasid } \\
\text { Finan }\end{array}$ & $\begin{array}{l}\text { Maqasid } \\
\text { Finan }\end{array}$ & $\begin{array}{c}\text { Maqasid } \\
\text { Finan }\end{array}$ & $\begin{array}{c}\text { Maqasid } \\
\text { Finan }\end{array}$ & $\begin{array}{c}\text { Maqasid } \\
\text { Finan }\end{array}$ & $\begin{array}{l}\text { Maqasid } \\
\text { Finan }\end{array}$ & $\begin{array}{c}\text { Maqasid } \\
\text { Finan }\end{array}$ \\
\hline \multirow{2}{*}{$\begin{array}{l}\text { Ln } \\
\text { (Wadiah) }\end{array}$} & $-2.83 \mathrm{e}-05$ & $0.00648^{*}$ & $0.00954^{* * * *}$ & $0.0110^{*} * * *$ & $0.0126^{* * * *}$ & $0.0210^{* * * *}$ & $0.0276^{* * * *}$ & $0.0315^{*}$ *** & $0.0431^{\text {******* }}$ \\
\hline & (0.00466) & $(0.00371)$ & (0.00319) & $(0.00305)$ & (0.00321) & (0.00356) & (0.00449) & (0.00504) & $(0.00840)$ \\
\hline \multirow[t]{2}{*}{$\mathrm{ROA}$} & 0.222 & 0.416 & 0.507 & 0.551 & 0.597 & 0.848 & 1.045 & 1.162 & 1.508 \\
\hline & $(0.581)$ & $(0.623)$ & $(0.644)$ & $(0.654)$ & $(0.667)$ & $(0.732)$ & $(0.785)$ & $(0.816)$ & $(0.924)$ \\
\hline \multirow{2}{*}{$\begin{array}{l}\text { Process } \\
\text { Index }\end{array}$} & -0.0177 & -0.00799 & -0.00342 & -0.00123 & 0.00108 & 0.0137 & 0.0235 & 0.0294 & $0.0467 *$ \\
\hline & $(0.0352)$ & (0.0328) & $(0.0318)$ & $(0.0314)$ & (0.0309) & $(0.0288)$ & $(0.0277)$ & $(0.0272)$ & $(0.0277)$ \\
\hline \multirow[t]{2}{*}{ Constant } & 0.0744 & -0.0195 & -0.0635 & -0.0847 & -0.107 & -0.228 & $-0.324 * *$ & -0.380 **** & -0.548 **** \\
\hline & $(0.174)$ & (0.159) & (0.153) & $(0.150)$ & (0.148) & $(0.141)$ & $(0.141)$ & (0.144) & $(0.172)$ \\
\hline Observations & 238 & 238 & 238 & 238 & 238 & 238 & 238 & 238 & 238 \\
\hline
\end{tabular}

Note: Standard errors in parentheses *** $\mathrm{p}<0.01,{ }^{*} * \mathrm{p}<0.05,{ }^{*} \mathrm{p}<0.1$. Instrumental variables on process index variable: $\ln (\mathrm{zakat}+\mathrm{qard}$ hassan + waqf), ROE, Altman Z-Score, ln(Net Interest Margin). 